\title{
Training with elastic and conventional devices on body composition: systematic review and meta-analysis
}

\author{
Treinamento em dispositivos elásticos e convencionais sobre \\ a composição corporal: revisão sistemática e meta-análise
}

\section{Entrenamiento en dispositivos elásticos y convencionales sobre composición corporal: revisión sistemática y metaanálisis}

Jaqueline Santos Silva Lopes (i) [a,b], Jales Fagundes da Silva Neto $\left({ }^{[b]}\right.$, Rayana Loch Gomes (i) [c],

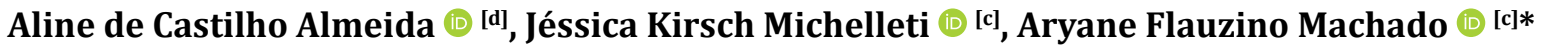

[a] Universidade Federal de Mato Grosso (UFMT), Cuiabá, MT, Brazil

${ }^{[b]}$ Centro Universidade do Vale do Araguaia (Univar), Barra do Garças, MT, Brazil

${ }^{[c]}$ Universidade Estadual Paulista (Unesp), Presidente Prudente, SP, Brazil

[d] Universidade Federal de São Carlos (UFSCar), São Carlos, SP, Brazil

\section{Abstract}

Introduction: Given the practicality and low cost of elastic devices, a comparison with conventional devices may be able to quantify gains from both tools for further conclusions. Objective: Compare the effect of resistance training with elastic (tubes and resistance band) and conventional (weight machines and dumbbells) devices on body composition. Method: This is a systematic review and meta-analysis. The PubMed/MEDLINE, Embase, PEDro and CENTRAL databases were searched from the earliest records to July 25, 2018. Data were described in standardized mean difference (SMD) with a 95\% confidence interval (95\% CI). Results: Four studies were

* JSSL: PhD, e-mail: jaqueee-santosss@hotmail.com JFSN: Undergrad, e-mail: jalesfagundes1@gmail.com RLG: PhD, e-mail: ray_loch@hotmail.com ACA: PhD, e-mail: calmeida.aline@gmail.com JKM: PhD, e-mail: jessicamicheletti@hotmail.com AFM: PhD, e-mail: ary_machado@hotmail.com 
included. The results of the meta-analysis did not show superiority among the analyzed methods for the variables investigated (SMD $=-2.04,95 \% \mathrm{CI}-7.56,3.48, \mathrm{p}<0.00001$, lean mass: SMD $=0.28,95 \% \mathrm{CI}-0.29,0.85$, $\mathrm{p}=0.97$, body fat: SMD $=2.77,95 \%$ CI $-0.05,5.59, \mathrm{p}=0.92$, body mass: SMD $=1.22,95 \%$ CI $-0.29,2.74, \mathrm{p}=0.11$ ). Conclusion: The results of the meta-analysis showed superiority of outcome from training in conventional devices only for the variable fat mass. For the other variables, no statistically significant differences were found. Elastic resistance can promote similar outcomes to resistance in different population profiles and from various protocols on variables related to body composition.

Keywords: Exercise. Physical Endurance. Body Weight. Physical Therapy Specialty.

\section{Resumo}

Introdução: Tendo em vista a praticidade e o baixo custo dos dispositivos elásticos, uma comparação com dispositivos convencionais (halteres e máquinas de peso) pode ser capaz de quantificar os resultados observados para posteriores conclusões sobre eventual tendência de superioridade verificada entre os métodos investigados. objetivo: Comparar o efeito do treinamento resistido em dispositivos elásticos (tubos e faixa elástica) e convencionais (máquinas de peso e halteres) sobre a composição corporal. Método: Trata-se de uma revisão sistemática e meta-análise. Foram pesquisadas as bases de dados PubMed/MEDLINE, Embase, PEDro e CENTRAL desde os registros mais antigos até 25 de julho de 2018. Os dados foram descritos em standardized mean difference (SMD) com intervalo de confiança de 95\% (95\% CI). Resultados: Quatro estudos foram incluídos. Os resultados da meta-análise não demonstraram superioridade entre os métodos analisados para as variáveis investigadas (massa gorda: $S M D=-2.04 ; 95 \%$ CI 7.56, 3.48; $p<0.00001$; massa magra: $S M D=0.28 ; 95 \%$ CI -0.29, 0.85; $p=0.97$; gordura corporal: $S M D=2.77 ; 95 \%$ CI -0.05, 5.59; $p=0.92$; massa corporal: $S M D=1.22 ; 95 \%$ CI -0.29, 2.74; $p=0.11)$. Conclusão: Houve superioridade de resultado apenas para a variável massa gorda, que demonstrou melhores resultados oriundos do treinamento em dispositivos convencionais. Para as demais variáveis, não foram identificadas diferenças estatisticamente significantes. A resistência elástica é capaz de promover desfechos similares a resistência convencional, em diferentes perfis de população e a partir de protocolos diversos sobre variáveis relacionadas a composição corporal.

Palavras-chave: Exercício. Resistência Física. Peso Corporal. Fisioterapia.

\section{Resumen}

Introducción: Debido a la practicidad y el bajo costo de los dispositivos elásticos, una comparación con los dispositivos convencionales (pesas y mancuernas) puede cuantificar los beneficios de ambas herramientas para obtener conclusiones adicionales. Objetivo: Comparar el efecto del entrenamiento de resistencia en dispositivos elásticos (tubos y banda elástica) y convencionales (pesas y mancuernas) en la composición corporal. Método: Esta es una revisión sistemática y metaanálisis. En las bases de datos PubMed/MEDLINE, Embase, PEDro y CENTRAL se buscaron desde los registros más antiguos hasta el 25 de julio de 2018. Los datos se describieron en la diferencia de medias estandarizada (DME) con un intervalo de confianza del 95\% (IC del 95\%). Resultados: Se incluyeron cuatro estudios. Los resultados del metaanálisis no mostraron una superioridad entre los métodos analizados para las variables investigadas (masa grasa, SMD=-2.04, IC 95\% -7.56, 3.48, $p<0,00001$, masa magra: $S M D=0.28$, IC 95\% -0.29, 0.85, $p=0,97$, grasa corporal: $S M D=2,77$, IC 95\% -0,05, 5,59, $p=0,92$, masa corporal: $S M D=1,22$, IC 95\% -0,29, 2,74, $p=0,11$ ). Conclusión: Hubo una superioridad de los resultados del entrenamiento en dispositivos convencionales solo para la variable masa grasa. Para las otras variables, no se encontraron diferencias estadísticamente significativas. La resistencia elástica es capaz de promover resultados similares a la resistencia convencional en diferentes perfiles de población y de varios protocolos sobre variables relacionadas con la composición corporal.

Palabras clave: Ejercicio. Resistencia Física. Peso Corporal. Fisioterapia. 


\section{Introduction}

Resistance exercises can be performed in different scenarios, with several implements such as dumbbells, weight machines, exercise balls, body mass and elastic devices [1-3]; and is an essential strategy in physical therapy rehabilitation protocols for any population profile as well as intended outcomes [4-8]. Studies have shown benefits from regular resistance exercise practice on cardiovascular parameters, quality of life, relief of chronic pain, increased functional independence, improved joint mobility, greater independence in daily activities, reduction in the incidence of injuries and self-esteem [9-11].

Despite the described benefits of using conventional devices for resistance training, their use comprise low accessibility conditions [12]. First, places that include such equipment often requires a monthly cost. Second, travel to these locations may be associated with logistical difficulties. Finally, it is worth highlighting the embarrassment that performing activities with other people may cause $[13,14]$. These factors may influence the dropout of a significant percentage of people who start this type of physical activity, and evidence shows that $50 \%$ of the public enrolled in gyms drop out during the first year [15].

In this scenario, an alternative method gaining popularity is the elastic device because of several advantages provided, such as its low cost, portability, accessibility, as well as the functional gains described in the literature [16-24]. Several studies highlight the effectiveness of elastic bands in therapeutic and preventive rehabilitation process under different conditions, in different profiles of healthy and sick population [11-19]. In addition, exercises with elastic devices can occur naturally, in places that provide greater comfort to the user [23].

Among the commonly described outcomes of resistance training, body composition represents an important parameter in disease control, treatment or prevention. This variable has been investigated in studies comparing elastic devices with conventional ones for resistance exercise $[16,19]$, with results showing changes related to decreased fat mass and increased lean mass. A study by Neves et al [25] found that reducing fat mass was responsible for improving functional mobility, agility and motor coordination.

Therefore, considering the published literature on the subject and the benefits of using elastic devices in training protocols, review studies comparing both strategies are relevant to quantitatively measure the magnitude of effects of both methods analyzed on body composition. To the authors' knowledge, this is the first systematic review and meta-analysis on the proposed subject.

It is hypothesized that the outcomes observed between both devices will be similar, serving as a parameter for future discussions regarding the suggestion of protocols that present elastic resistance, to control variables also related to body composition. Thus, this review study aimed to compare the effect of resistance training with elastic (tubes and resistance band) and conventional (weight machines and dumbbells) devices on body composition.

\section{Method}

This study was registered in the International Prospective Register of Systematic Reviews (PROSPERO) under protocol CRD42016042152. The Preferred Reporting Items for Systematic Reviews and Meta-Analyzes (PRISMA) guidelines were followed in order to describe all the necessary items for a high quality systematic review and meta-analysis.

\section{Search strategy}

Studies were selected from the following databases: PubMed / MEDLINE, PEDro (Physiotherapy Evidence Database), EMBASE, and Cochrane Central Register of Controlled Trials (CENTRAL) from the earliest records to July 25th, 2018. Terms and keywords related to randomized controlled trial, elastic band, and body composition were used. Manual search in the eligible studies list of references was performed as a complement. No restriction on the condition of the sample (age, gender, clinical condition), publication date, or language was stablished for study inclusion.

\section{Study selection}

Studies that compared training performed by elastic devices (tubes and resistance bands) 
with conventional devices (weight machines and dumbbells) were selected. Inclusion criteria were: 1) randomized clinical trial comparing training performed with elastic resistance and training on weight machines and/or free weights; 2) evaluated body composition as outcome. All types of elastic resistance were eligible for inclusion. The study selection process was conducted in stages (title, abstract and full text) by two independent evaluators.

\section{Data extraction}

Relevant information on study characteristics such as design, participant characteristics, description of training protocols for both groups, outcomes assessed, and PEDro scale were extracted from a standardized form (Table 1 ).

\section{Methodological quality assessment}

The included studies were evaluated for their methodological quality by the PEDro scale (0-10). Thus, each study was evaluated for eligibility criteria, random allocation, secret allocation, baseline comparison, subjects, therapists and evaluators blindly, followup with less than $15 \%$ loss, appropriate treatment according to allocation or intention to treat, intergroup statistical comparisons and measures of precision, and variability. For clinical trials already evaluated, the PEDro scale value contained in the database was used. Methodological quality was not considered an inclusion criterion.

\section{Statistical analysis}

Data were analyzed using the Review Manager (RevMan, version 5.3.5), grouped in meta-analysis and reported as standardized mean difference (SMD) with 95\% confidence interval (CI).

\section{Results}

\section{Study characteristics}

The literature search obtained a total of 321 studies after duplicate exclusion, of which 18 were considered eligible after exclusion by title, abstract and full text. Of these, 14 studies were excluded for not comparing training between elastic devices and conventional machines (all compared elastic resistance with control condition). Thus, four articles (Table 1) met the inclusion criteria, comprising 182 individuals aged between 15 and 67 years old. Regarding health aspect, the sample ranged from physically active individuals $[6,16,26]$ to individuals with moderate COPD [19]. Publication dates varied between 2008 and 2014. No articles were found in the manual search of the bibliographic references of the review.

The included studies were conducted in different countries, such as Brazil [19], Spain [6, 26] and Australia [16].

The duration of the training protocols used in the included studies ranged from 8 to 12 weeks with frequency of 2 to 3 times per week. The characteristics of the included studies are summarized in Table 1.

Table 1 - Characteristics of the included studies

\begin{tabular}{|c|c|c|c|c|c|c|}
\hline Study, year & $\begin{array}{l}\text { Characteristics } \\
\text { of participants }\end{array}$ & Protocol used & $\begin{array}{c}\text { Type of } \\
\text { intervention }\end{array}$ & Outcomes analyzed & Variables analyzed & $\begin{array}{l}\text { PEDro } \\
\text { Score }\end{array}$ \\
\hline $\begin{array}{c}\text { Colado et al., } \\
2008\end{array}$ & $\begin{array}{c}\mathrm{N}=35 \text { women } \\
54.14 \pm 2.87 \\
\text { years old }\end{array}$ & $\begin{array}{l}10 \text { weeks } \\
\text { (2 sessions/ } \\
\text { week) }\end{array}$ & $\begin{array}{c}\text { CR: Weight } \\
\text { machine; } \\
\text { ER: thera band. }\end{array}$ & Body composition & $\begin{array}{l}\text { Fat mass; } \\
\text { Lean mass. }\end{array}$ & 6 \\
\hline $\begin{array}{c}\text { Colado et al., } \\
2012\end{array}$ & $\begin{array}{c}\mathrm{N}=35 \text { women } \\
54.14 \pm 2.87 \\
\text { years old }\end{array}$ & $\begin{array}{l}10 \text { weeks } \\
\text { (2 sessions/ } \\
\text { week) }\end{array}$ & $\begin{array}{c}\text { CR: Weight } \\
\text { machine; } \\
\text { ER: thera band. }\end{array}$ & Body composition & $\begin{array}{l}\text { Fat mass; } \\
\text { Lean mass. }\end{array}$ & 6 \\
\hline $\begin{array}{l}\text { Lubans et al., } \\
2010\end{array}$ & $\begin{array}{c}N=36 \\
\text { adolescents } \\
\text { Age: } 15.0 \pm 0.7 \\
\text { years old }\end{array}$ & $\begin{array}{c}8 \text { weeks } \\
\text { (2 sessions/ } \\
\text { week) }\end{array}$ & $\begin{array}{l}\text { CR: Weight } \\
\text { machine; } \\
\text { ER: elastic tube }\end{array}$ & Body composition & $\begin{array}{l}\text { Lean mass; } \\
\text { Fat mass; } \\
\text { Total fat; } \\
\text { BMl; }\end{array}$ & 7 \\
\hline $\begin{array}{c}\text { Ramos et al., } \\
2014\end{array}$ & $\begin{array}{c}\mathrm{N}=34 \text { patients } \\
\text { diagnosed with } \\
\text { COPD } \\
\text { Average age: } 66 \\
\text { years old }\end{array}$ & $\begin{array}{c}8 \text { weeks } \\
\text { (3 sessions/ } \\
\text { week) }\end{array}$ & $\begin{array}{c}\text { CR: Weight } \\
\text { machine; } \\
\text { ER: elastic tube }\end{array}$ & Body composition & Lean mass & 8 \\
\hline
\end{tabular}

Note: CR: conventional resistance training; ER: elastic resistance training. 
Methodological quality of included studies

The methodological quality assessment of the included studies using the PEDro scale reported an 6.75 average. One study [19] scored 8; one [16] scored 7; and two scored 6 on the scale, if the articles were classified as "moderate quality" $[6,26]$.

Effects of resistance training and weight resistance on body composition

The outcomes analyzed refer to lean mass, fat mass, total body fat and body mass index (BMI).

Regarding fat mass, two studies showed superior results for fat mass reduction from conventional training whereas one study favored training with elastic resistance. A statistically significant difference was also observed, with a higher level of evidence for conventional training (SMD $=-2.04$; 95\% CI -7.56, 3.48; $\mathrm{p}<0.00001$ ). The described values are shown in Figure 1.
The four studies favored training performed on elastic devices for the variable lean mass, but there was no statistically significant difference, as observed in Figure 2, with data showing similarity between the analyzed outcomes (SMD $=0.28 ; 95 \%$ CI -0.29, 0.85; $p=0.97$ ).

Regarding the total body fat percentage, only Lubans et al. [16] verified this variable. Comparing individuals of both sexes, the study found that training with elastic devices had superior results for both men and women, as shown in Figure 3. However, this data was insufficient to show a statistically significant difference $(\mathrm{SMD}=2.77$; 95\% CI -0.05, 5.59; $\mathrm{p}=0.92$ ).

Finally, the analysis regarding body mass index (Figure 4) showed superior results for training with elastic devices, but no statistically significant difference was observed between the groups. This data shows similar results from the analyzed methods regarding physical training with conventional and elastic devices (SMD $=1.22 ; 95 \%$ CI $-0.29,2.74 ; \mathrm{p}=0.11$ ).

\begin{tabular}{|c|c|c|c|c|c|c|c|c|c|c|c|}
\hline \multirow[b]{2}{*}{ Study or Subgroup } & \multicolumn{3}{|c|}{ Convencional } & \multicolumn{3}{|c|}{ Tubo } & \multirow[b]{2}{*}{ Weight } & \multirow{2}{*}{$\begin{array}{r}\text { Mean Difference } \\
\text { IV, Random, } 95 \% \text { CI }\end{array}$} & \multirow{2}{*}{\multicolumn{2}{|c|}{$\begin{array}{c}\text { Mean Difference } \\
\text { IV, Random, 95\% CI }\end{array}$}} & \\
\hline & Mean & SD & TOTAL & Mean & SD & TOTAL & & & & & \\
\hline Colado et al., 2008 & 21.2 & 5.7 & 14 & 27.8 & 7.1 & 21 & $24.6 \%$ & $-6.60[-10.86,-2.34]$ & —- & & \\
\hline Colado et al., 2012 & 21.1 & 1.5 & 14 & 27.8 & 1.5 & 21 & $28.6 \%$ & $-6.70[-7.71,-5.69]$ & $=$ & & \\
\hline Lubans et al., 2010a & 12 & 11.5 & 15 & 8.2 & 3.6 & 21 & $21.5 \%$ & $3.80[-2.22,9.82]$ & & & \\
\hline Lubans et al., 2010b & 16.3 & 8 & 22 & 13.6 & 4.1 & 20 & $25.4 \%$ & $2.70[-1.10,6.50]$ & & & \\
\hline Total $(95 \% \mathrm{Cl})$ & & & 65 & & & 83 & $100.0 \%$ & $-2.04[-7.56,3.438]$ & & & \\
\hline \multicolumn{12}{|c|}{ Heterogeneity: $\mathrm{Tau}^{2}=27.52 ; \mathrm{Ch}^{2}=32.18, \mathrm{df}=3(\mathrm{P}<0.00001) ;\left.\right|^{2}=91 \%$} \\
\hline \multicolumn{8}{|c|}{ Test for overall effect: $Z=0.72(P=0.47)$} & & $\begin{array}{l}-10 \\
\text { [convencior }\end{array}$ & $\begin{array}{l}0 \\
\text { Favours [t] }\end{array}$ & $\begin{array}{c}10 \\
\text { ubo] }\end{array}$ \\
\hline
\end{tabular}

Note: SD: standard deviation; Std: standardized; Cl: confidence interval.

Figure 1 - Forest plot illustrating the effect of training with elastic versus conventional devices on fat mass outcome.

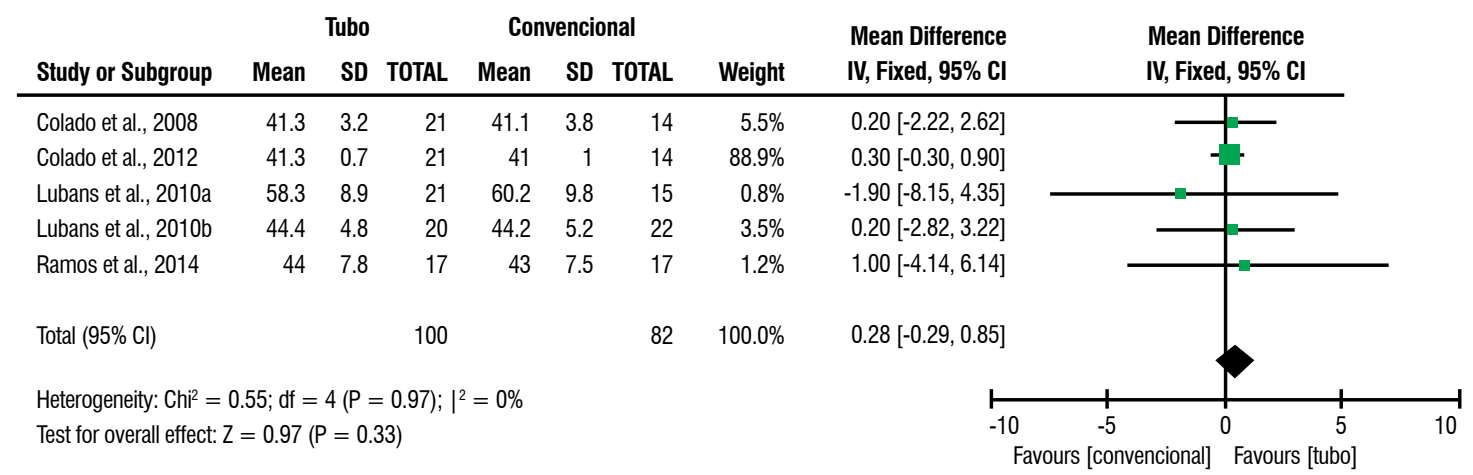

Note: SD: standard deviation; Std: standardized; Cl: confidence interval.

Figure 2 - Forest plot illustrating the effect of training with elastic versus conventional devices on lean mass outcome. 
Lopes JSS, Silva Neto JF, Gomes RL, Almeida AC, Michelleti JK, Machado AF.

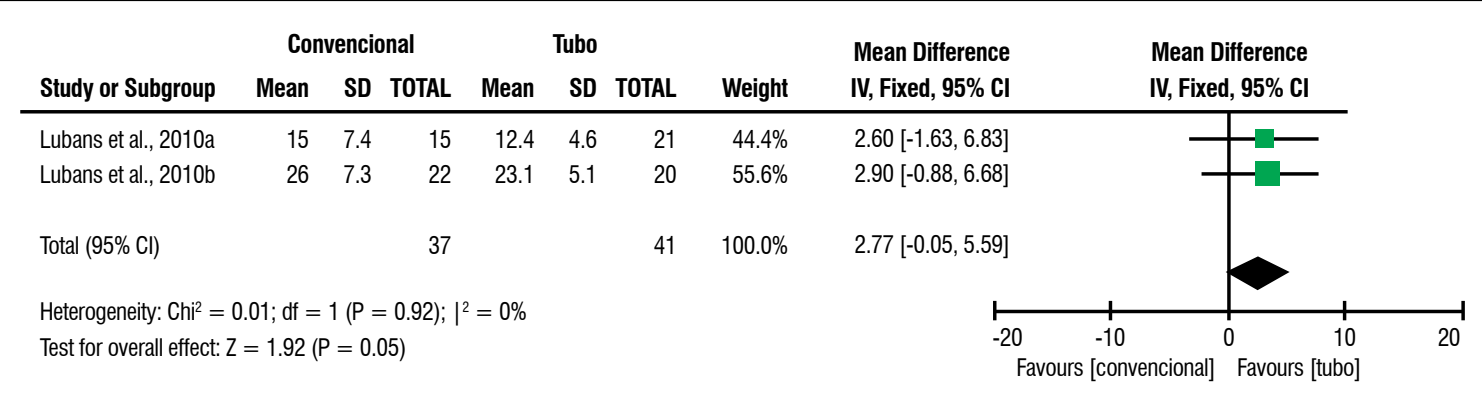

Figure 3 - Forest plot illustrating the effect of training on elastic versus conventional devices on body fat outcome.

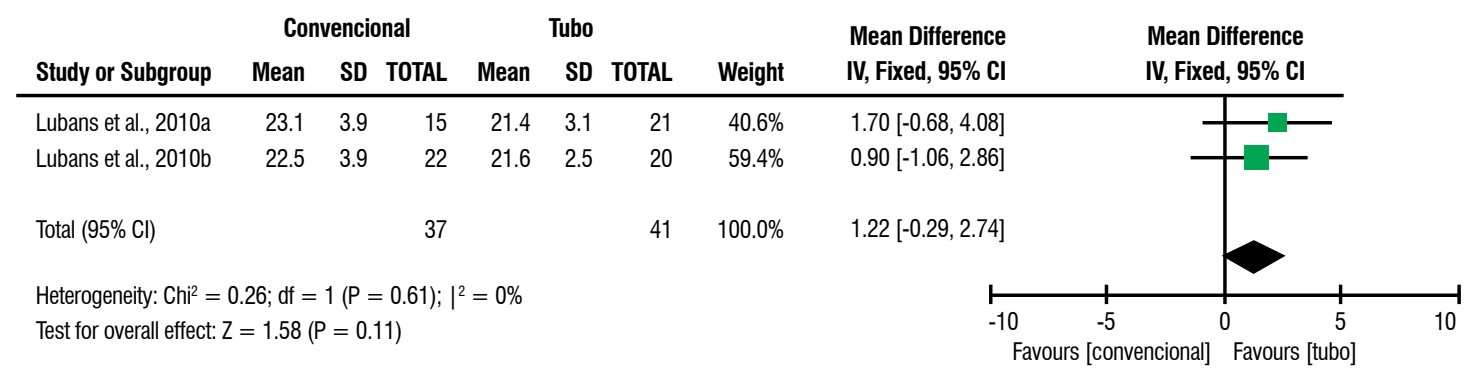

Note: SD: standard deviation; Std: standardized; Cl: confidence interval.

Figure 4 - Forest plot illustrating the effect of training with elastic versus conventional devices on body mass index (BMI) outcome.

\section{Discussion}

This systematic review and meta-analysis showed that resistance training with conventional devices had superior results only for fat mass reduction, where a statistically significant difference was observed. For the other analyzed variables (lean mass, total fat and BMI), no statistically significant differences were found between changes in body composition, based on resistance training in the analyzed devices.

Not defining a population with homogeneous characteristics allowed for holistic perception regarding the analyzed methods and similar conclusions to other studies $[16,19,23]$. Regarding this aspect, a recently published review and metaanalysis [27], when comparing different population profiles, found similar results between conventional and elastic devices for muscle strength gain.

Several studies use body composition analyzes as an important parameter on the effect of therapeutic interventions used in therapeutic and preventive programs $[28,29]$, to evaluate progress or worsening rates. In this respect, the results of this study provide evidence of an alternative method of practical applications, expanding the characteristics of individuals who may benefit from resistance training with elastic tubes.
Other studies have also found positive results regarding the use of elastic devices in resistance training protocols in different scenarios [18, 30-32]. This fact enhances the possibilities of its use in clinical and scientific contexts, in healthy and sick populations [33-35].

To the authors' knowledge, this is the first systematic review and meta-analysis to investigate the effect of resistance training on body composition comparing elastic and conventional devices. A limitation of this study is the lack of load standardization for elastic resistance training [36-38]. The gaps regarding the standardization of load dynamics and training prescription for this device are notorious.

Strengths of this study are the search strategy used, without restriction of sample or time, and despite the low number of included studies, the PEDro scale was used to ensure its high methodological quality to demonstrate reliable and well-founded scientific results that intend to fill gaps in the literature about the proposed topic.

The findings of this study are relevant for clinical and scientific practice [36-38] in providing important evidence on an alternative method considering low cost and accessibility. Seeing as these results are limited to the investigated populations; new studies should be conducted to stablish the dose response on different intensities and groups. 


\section{Conclusion}

Data shows superior results for training with conventional devices only for fat mass. For the other variables, no statistically significant differences were found. Elastic resistance can promote similar responses to conventional resistance, in different population profiles and from different protocols, on variables related to body composition.

However, the benefits of this alternative method should the considered, which includes logistical ease, portability and low cost. Moreover, the presented data cannot be extrapolated to population profiles not included in the present study.

\section{References}

1. Park SY, Yoo WG, An DH, Jung-hoon L. Comparison of isometric exercises for activating latissimus dorsi against the upper body weight. J Electromyogr Kinesiol. 2015;25(1):47-52.

2. Escamilla RF, Lewis C, Pecson A, Imamura R, Andrews JR. Muscle Activation Among Supine, Prone, and Side Position Exercises with and without a Swiss Ball. Sports Health. 2016;8(4):372-9.

3. Lima FF, Camillo CA, Gobbo LA, Trevisan IB, Nascimento WBBM, Silva BSA, et al. Resistance Training using Low Cost Elastic Tubing is Equally Effective to Conventional Weight Machines in Middle-Aged to Older Healthy Adults: A Quasi-Randomized Controlled Clinical Trial. J Sports Sci Med. 2018;17(1)153-60.

4. Silva NL, Oliveira RB, Fleck SJ, Leon ACMP, Farinatti P. Influence of strength training variables on strength gains in adults over 55 years-old: a meta-analysis of dose-response relationships. J Sci Med Sport. 2014;17(3):337-44.

5. Colado JC, Garcia-Masso X, Triplett TN, Flandez J, Borreani S, Tella V. Concurrent validation of the OMNIresistance exercise scale of perceived exertion with Thera-band resistance bands. J Strength Cond Res. 2012;26(11):3018-24.

6. Colado JC, Garcia-Masso X, Rogers ME, Tella V, Benavent J, Dantas EH. Effects of aquatic and dry land resistance training devices on body composition and physical capacity in postmenopausal women. J Hum Kinet. 2012;32:185-95.
7. Chodzko-Zajko W, Proctor DN, Singh MF, Minson C, Nigg C, Salem G, et al. Exercise and physical activity for older adults. Med Sci Sports Exerc. 2009;41(7):1510-30.

8. Lopes JSS, Machado AF, Cavina AP, Micheletti JK, Almeida AC, Pastre CM. Specific interventions for prevention of muscle injury in lower limbs: systematic review and meta-analysis. Fisioter Mov. 2019;32:e003224.

9. Liao CD, Tsauo JY, Huang SW, Ku JW, Hsiao DJ, Liou TH. Effects of elastic band exercise on lean mass and physical capacity in older women with sarcopenic obesity: A randomized controlled trial. Sci Rep. 2018;8(1):2317.

10. Garber CE, Blissmer B, Deschenes MR, Franklin BA, Lamonte MJ, Lee IM, et al. American College of Sports Medicine position stand. Quantity and quality of exercise for developing and maintaining cardiorespiratory, musculoskeletal, and neuromotor fitness in apparently healthy adults: guidance for prescribing exercise. Med Sci Sports Exerc. 2011;43(7):1334-59.

11. Penedo FJ, Dahn JR. Exercise and well-being: a review of mental and physical health benefits associated with physical activity. Curr Opin Psychiatry. 2005;18(2):189-93.

12. Keogh JWL, MacLeod RD. Body composition, physical fitness, functional performance, quality of life, and fatigue benefits of exercise for prostate cancer patients: a systematic review. J Pain Symptom Manage. 2012;43(1):96-110.

13. Melo CC, Boletini TL, Mares DP, Noce F. Fatores que influenciam a evasão de clientes em uma academia: estudo de caso. Rev Bras Psicol Esporte. 2017;7(2):57-69.

14. Liz CM, Andrade A. Qualitative analysis of the reasons to the adhesion and desistance to the practice of resistance exercises in gyms. Rev Bras Cienc Esporte. 2016;38(3):267-74.

15. Dishman RK, Heath GW, Washburn R. Physical Activity Epidemiology. Champaign: Human Kinetics; 2004. 
16. Lubans DR, Sheaman C, Callister R. Exercise adherence and intervention effects of two school-based resistance training programs for adolescents. Prev Med. 2010;(50):56-62.

17. Ghigiarelli JJ, Nagle EF, Gross FL, Robertson RJ, Irrgang JJ, Myslinski T. The effects of a 7-week heavy elastic band and weight chain program on upperbody strength and upper-body power in a sample of division 1-AA football players. J Strength Cond Res. 2009;23(3):756-64.

18. Martins WR, Oliveira RJ, Carvalho RS, Damasceno VO, Silva VZM, Silva MS. Elastic resistance training to increase muscle strength in elderly: A systematic review with meta-analysis. Arch Gerontol Geriatr. 2013;57(1):8-15.

19. Ramos EMC, Toledo-Arruda AC, Fosco LC, Bonfim R, Bertolini GN, Guarnier FA, et al. The effects of elastic tubing-based resistance training compared with conventional resistance training in patients with moderate chronic obstructive pulmonary disease: a randomized clinical trial. Clin Rehabil. 2014;28(11) 1096-106.

20. Colado JC, Garcia-Masso X, Pellicer M, Alakhdar Y, Benavent J, Cabeza-Ruiz R. A Comparison of Elastic Tubing and Isotonic Resistance Exercises. Int J Sports Med. 2010;31(11):810-7.

21. Webber SC, Porter MM. Effects of Ankle Power Training on Movement Time in Mobility-Impaired Older Women. Med Sci Sports Exerc. 2010;42(7):1233-40.

22. Calatayud J, Borreani S, Colado JC, Martin F, Tella V, Andersen LL. Bench press and push-up at comparable levels of muscle activity results in similar strength gains. J Strength Cond Res. 2015;29(1):246-53.

23. Vanbiervliet $\mathrm{W}$, Pélissier W, Lédermann B, Kotzki N, Benaïm C, Hérisson C. Le renforcement musculaire par bandes élastiques: évaluation de ses effets dans le réentraînement à l'effort du coronarien. Ann Readapt Med Phys. 2003;46(8):545-52.

24. Silva BSA, Gobbo LA, Freire APCF, Trevisan IB, Silva IG, Ramos EMC. Effects of a resistance training with elastic tubing in strength, quality of a life and dyspnea in patients with chronic obstructive pulmonary disease. J Phys Educ. 2016;27:e2722.
25. Neves LM, Fortaleza ACS, Rossi FE, Diniz TA, Castro $\mathrm{MR}$, Aro BL, et al. Efeito de um programa de treinamento funcional de curta duração sobre a composição corporal de mulheres na pós-menopausa. Rev Bras Ginecol Obstet. 2014;36(9):404-9.

26. Colado JC, Triplett T. Effects of a short-term resistance program using elastic bands versus weight machines for sedentary middle-aged women. J Strength Cond Res 2008;22(5):1441-8.

27. Lopes JSS, Machado AF, Micheletti JK, Almeida AC, Cavina AP, Pastre CM. Effects of training with elastic resistance versus conventional resistance on muscular strength: A systematic review and meta-analysis. SAGE Open Med. 2019;7:1-7.

28. Jensen MD, Ryan DH, Apovian CM, Ard JD, Comuzzie AG, Donato KA, et al. AHA/ACC/TOS guideline for the management of overweight and obesity in adults: a report of the American College of Cardiology/American Heart Association Task Force on practice guidelines and the Obesity Society. Circulation. 2014;129:S102-38.

29. U.S. Department of Health and Human Services. The Surgeon General's Call to Action to Prevent and Decrease Overweight and Obesity. Washington, DC: Office of the Surgeon General; 2001.

30. Lange AK, Vanwanseele B, Fiatarone Singh MA. Strength training for treatment of osteoarthritis of the knee: a systematic review. Arthritis Care Res. 2008;59(10):1488-94.

31. Busch AJ, Webber SC, Richards RS, Bidonde J, Schachter CL, Schafer LA, et al. Resistance exercise training for fibromyalgia. Cochrane Database Syst Rev. 2013;(12):CD010884.

32. Colado JC, Triplett NT, Tella V, Saucedo P, Abellán J. Effects of aquatic resistance training on health and fitness in postmenopausal women. Eur J Appl Physiol. 2009;106(1):113-22.

33. Thomas M, Müller T, Busse MW. Quantification of tension in Thera-Band and Cando tubing at different strains and starting lengths. J Sports Med Phys Fitness. 2005;45(2):188-98. 
34. Gordon SJ, Grimmer KA, Baker N, Bell E, Coveney J, Jordaan J H, et al. Feasibility of population screening tests to establish a healthy ageing trajectory. SAGE Open Med. 2019;7:1-9.

35. Simo VE, Jiménez AJ, Guzmán FM, Oliveira JC, Nicolas MF, Potau MP, et al. Beneficios del ejercicio físico de baja intensidad durante la sesión de hemodiálisis en el paciente anciano. Nefrologia. 2015; 35(4):385-94.

36. Lopes JSS, Micheletti JK, Machado AF, Souto LR, Lima HP, Vanderlei FM, et al. Test-retest reliability of knee extensors endurance test with elastic resistance. PLoS One. 2018; 13(8):e0203259.

37. Micheletti JK, Pastre CM, Machado AF, Souto LS, Silva JS, Andersen LL. Determination of Shoulder Abduction Strength Using a Submaximal Elastic Band Test. J Perform Health Res. 2017;1(2):31-9.
38. Micheletti JK, Andersen LL, Machado AF, Lopes JSS, Souto LR, Pastre CM. Reliability of shoulder muscle endurance tested using elastic bands. Med Sport. 2019;72(1):139-51.

Received in $04 / 26 / 2019$

Recebido em 26/04/2019

Recibido em 26/04/2019

Approved in 01/07/2020

Aprovado em 07/01/2020

Aprobado em 07/01/2020 